\title{
COMPARISON OF A GENUS-SPECIFIC CONVENTIONAL PCR AND A SPECIES-SPECIFIC NESTED-PCR FOR MALARIA DIAGNOSIS USING FTA COLLECTED SAMPLES FROM KINGDOM OF SAUDI ARABIA
}

\author{
By \\ SAEED A. AL-HARTHI \\ Department of Parasitology, Faculty of Medicine, Umm AL-Qura University, P.O. Box \\ 13955 Makkah, 21955, Saudi Arabia. Makkah, Kingdom of Saudi Arabia \\ (e-mail: sasharthi@uqu.edu.sa.)
}

\begin{abstract}
Molecular tools are increasingly accepted as the most sensitive and reliable techniques for malaria diagnosis and epidemiological surveys. Also, collection of finger prick blood spots onto filter papers is the most simple and affordable method for samples preservation and posterior molecular analysis, especially in rural endemic regions where malaria remains a major health problem. Two malaria molecular diagnostic tests, a Plasmodium genus-specific conventional PCR and a Plasmodium species-specific Nested PCR, were evaluated using DNA templates prepared from WhatmanFTA $^{\circledR}$ cards' dry blood spots using both, Methanol-fixation/Heat-extraction and FTA ${ }^{\circledR}$ commercial purification kit. A total of 121 blood sam-ples were collected from six Saudi south-western endemic districts both, as thick and thin films for routine microscopic screening and onto FTA ${ }^{\circledR}$ cards for molecular studies.

Out of the 121 samples, 75 were $P$. falciparum positive by at least one technique. No other species of Plasmodium were detected. $P$. falciparum parasites were identified in 69/75 (92\%) samples by microscopic screening in health care centers. $P$. genus-specific PCR was able to amplify $P$. falciparum DNA in 41/75 (55\%) and 59/75 (79\%) samples using Methanol-fixation/Heat-extraction and FTA ${ }^{\circledR}$ purification kit, respectively. $P$. species-specific Nested PCR revealed 68/75 (91\%) and $75 / 75(100 \%)$ positive samples using DNA templates were isolated by Methanol-fixation/Heatextraction and FTA ${ }^{\circledR}$ purification methods, respectively.

The species-specific Nested PCR applied to Whatman-FTA ${ }^{\circledR}$ preserved and processed blood samples represents the best alternative to classical microscopy for malaria diagnosis, particularly in epidemiological screening.
\end{abstract}

Key words: Malaria diagnosis, Saudi Arabia, PCR, Nested-PCR, FTA ${ }^{\circledR}$ cards.

\section{Introduction}

Malaria is considered as the most common vector-borne disease worldwide. Human malaria is caused by protozoan parasites belonging to the Plasmodium genus, namely: P. falciparum, $P$. vivax, $P$. malariae, $P$. ova$l e$, and P. knowlesi, transmitted by Anopheles blood-feeding female mosquitoes (Tuteja, 2007; Daneshvar et al, 2009). P. falciparum is responsible for malignant malaria cases, being the most lethal form of the disease (Mbugi et al, 2006). According to the World Health Organization, 207 million cases of malaria were reported and approximately 627000 deaths worldwide. 3.4 billion People are considered at risk of acquiring the infection in 97 countries (WHO,
2013). Furthermore, malaria is now spreading to areas previously free of the disease. Also, millions of people travel each year from non-endemic regions to areas of malaria transmission where they get exposed to the disease. Many studies indicated the high risk of transmitting malaria by blood transfusion when no approved laboratory tests are applied to screen the blood for malaria (Pomper et al, 2003).

In Saudi Arabia, except for the central part which is free of malaria, the rest of the country includes malarious areas that differ in their epidemiological characteristics and the mosquito vector, though malaria vector, which is extremely well adapted to desert conditions occurs in all areas. Malaria epi- 
demiological aspect varies also in the same place, from one year to another, and it was affected by the control measures taken against malaria (Al-Seghayer et al, 1999; $\mathrm{MOH}, 2005)$. Malaria is endemic in the lowlands of Aseer region in the south-western province and particularly present in southern province of Jazan where $P$. falciparum accounts for about $85-90 \%$ reported cases, and where disease existence was perpetuated by continuous importation from neighbouring Yemen (Vassallo et al, 1985; El-Sebai and Makled, 1987; Warrell, 1993). Reported malaria cases in Saudi Arabia decreased every year. In 2003, a total of 1724 confirmed cases were reported, of which 582 were endogenous. Compared to 15,666 reported cases in 1990; the Ministry of Health took initiative for strengthening malaria control activities in the country (WHO, 2005). But, there was always a high risk for perpetuating malaria in endemic foci, as well as introduction of the disease to non-endemic areas by the important number of visitors coming for work or Ummrah and Hajj, in particular from endemic countries (Al-Hassan and Roberts, 2002; Alkhalife, 2003; Al-Tawfiq, 2006). Therefore, to prevent malaria transmission and spread, and achieved the goal of malaria elimination in KSA, new measures will be required through active detection and treatment of local and imported cases.

Malaria can be diagnosed by clinically, but the disease may be misdiagnosed because it shares signs and symptoms with other tropical illnesses (Wongsrichanalai et al, 2007) as typhoid fever, rheumatic fever, and bacterial meningitis. Microscopy of the Giemsastained thick and thin films was the standard laboratory diagnostic technique for identifying malaria infections very long age, but technique was capable of reliable diagnosis only when done by skilled microscopists using defined protocols (Avila and Ferreira, 1996; Cheesbrough, 1998). The nicroscopybased diagnosis was tedious and suffered low sensitivity when the parasitaemia levels were few. Several diagnostic techniques have been developed for diagnosis as dark field microscopy, immunoflueorescent antibody tests, quantitative-buffy-coat (QBC), several enzyme immunoassays, and western blotting, but most of them showed complications for field applications and insufficient sensitivity (Cheesbrough, 2009). The serological tests based on detection of antiPlasmodium antibodies were always hindered by relatively low specificity and inability to distinguish between past and recent infections (Gilles and Warrell, 2002). Several immunochromographic blood tests were developed for specific detection of Plasmodium parasites genus-specific or even species specific circulating antigens like HRP 2 and $\mathrm{pLDH}$ molecules. The evaluation of different rapid diagnostic tests, based either on monoclonal or polyclonal antibodies against plasmodium parasites antigens, showed varied specificity grades (Humar et al, 1997; Forney et al, 2001; Wongsrichanalai et al, 2007; Cheesbrough, 2009). The development of several molecular tools such as PCR and others derived methods like Nested-PCR and Multiplex-PCR protocols could overcome almost all handicaps presented by the former assays. Many molecular techniques showed high diagnostic indices and accuracy as confirmatory diagnostic tools in suspicious patients, especially when parasitaemia levels are very low to be detected by standard microscopic examination (Al-Harthi and Jamjoom, 2008). The frequency of asymptomatic careers detected by PCR methods were always much grea-ter than those diagnosed by conventional microscopic examination of stained thick blood films (Coura et al, 2006). More sophisticated molecular tools like Real-time PCR were introduced for malaria parasites detection in patient's samples; however their use for standard screening was highly limited by the high cost of reagents and needed infrastructure (AnnLee et al, 2002; Perandin et al, 2004; Mangold et al, 2005).

Polymerase chain reaction is becoming relevant for malaria control and elimination 
strategies in endemic areas with high incidences of chronic and asymptomatic cases. Because of their important diagnostic indices, some PCR assays were regarded as the gold standard method in many settings and health facilities (Proux et al, 2011). Collection of finger prick blood spots onto filter papers emerged as simplest and affordable alternative to whole blood collection, transportation, and processing for the molecular analysis in particular from rural areas (AlHarthi and Jamjoom, 2008; Ataei et al, 2011; Pieter et al, 2014).

In this study, two different molecular diagnostic techniques, a Plasmodium gen- usspecific conventional PCR (Cicerone et al, 1999) and a Plasmodium species-specific Nested PCR (Snounou et al, 1993; Singh et $a l, 1996)$, was assessed for diagnosis using DNA templates prepared from dry blood spots collected from endemic Saudi southwestern endemic areas on commercial FTA cards. Two DNA isolation protocols, Methanol-fixation/Heat-extraction and the FTA $^{\circledR}$ commercial purification system, were compared using both PCR techniques.

\section{Materials and Methods}

Blood samples collection and storage: Samples and patients' data collection was coordinated with Jazan District Local Health Authorities, including the National Centre for Training and Research of Tropical Diseases in Jazan. Samples were collected from health care centers in south-western endemic foci of Samtah, Al-Ardah, Jazan, Tiwal, Baisha, and Fifa mainly during high transmission seasons of years 2009-2012, between January and May. A total of 121 samples were collected from different febrile patients complaining of malaria associated symptoms as considered by physicians on duty, after their consent. All blood samples were collected in quadruplicate onto Whatman-FTA $^{\circledR}$ filter cards (Whatman, Florham Park, NJ), air dried, labelled and stored at room temperature in separated plastic bags. Three negative whole blood samples collected in EDTA-treated tubes \& on FTA ${ }^{\circledR}$ cards from healthy individuals living in non-endemic areas as negative controls. 3D7 P. falciparum reference strain cultured parasites spotted on FTA ${ }^{\circledR}$-cards, kindly provided by Liverpool School of Tropical Medicine, was used as positive control.

Microscopic examination: For each patient, thick and thin blood films were prepared and air-dried at room temperature. Only thin blood smears were fixed in methanol before staining. Both films were stained with $1 \%$ Giemsa stain in PBS. The films were then examined for malaria parasites using oil immersion objective (x100). Parasitaemia level was determined on thick smears as $1+$ for 1-10 parasites per 100 fields; $2+$ for 11 100 parasites per 100 fields; $3+$ for $1-10$ parasites per a single field; $4+$ for more than 10 parasites per single field (WHO, 1991). At least 100 thick film fields were examined before a slide was considered negative. Parasite species and stages were confirmed using thin blood films.

DNA templates preparation: Two approaches were used for DNA templates preparation from snipped dry blood spots, Methanol-fixation/Heat-extraction and the FTA ${ }^{\circledR}$ commercial purification Kit. First, one $5 \mathrm{~mm}$ diameter and two $2.5 \mathrm{~mm}$ diameter pieces were cut from dry blood spots on FTA ${ }^{\circledR}$ filter papers for each sample by using a clean punch. Methanol-fixation/Heat-extraction was done by fixation of $5 \mathrm{~mm}$ diameter snippet in $500 \mu 1$ of absolute methanol for 15 minutes at room temperature. Methanol solution was discarded and the vial left open on its side until complete evaporation of remaining methanol. $300 \mu 1$ of PCR-grade water was added and the snippet was heated for 15 minutes at $98^{\circ} \mathrm{C}$. During its heat incubation, the tube was vigorously vortexed for approximately one minute at intervals of 5 minutes. The snippet was then removed by a micropipette tip and extracted DNA concentrated in a vacuum-heat concentrator to a final volume of $40 \mu 1$ and stored at $-20^{\circ} \mathrm{C}$. 2.5 $\mathrm{mm}$ diameter snippets were separately treated by Whatman-FTA ${ }^{\circledR}$ commercial reagent 
(Whatman, Florham Park, NJ) and TE buffer following the procedure recommended by the manufacturer. The snippets were washed three times at room temperature in $0.2 \mathrm{ml}$ PCR tubes by using $100 \mu 1$ of FTA $^{\circledR}$ purification reagent by moderate manual rocking, for $5 \mathrm{~min}$. each. Then, the snippets were rinsed twice in $200 \mu 1$ of TE buffer for 5 minutes, and used directly in PCR reactions.

Molecular assays: Two PCR techniques targeting Plasmodium 18S SSU rRNA genes in malaria were applied to DNA templates prepared as described above; a conventional $P$. genus-specific PCR using Ssufw/Ssurv set of oligonucleotides adapted from Ciceron et al. (1999) and a $P$. species-specific Nested-PCR using two sets of primers, rPLU6/ rPLU5 in the first reaction and (Pff/Pfr plus $P v \mathrm{f} / P v \mathrm{r})$ in the Nested one to detect and discriminate between $P$. falciparum and $P$. vivax adapted from Snounou et al. (1993) (Tab. $1)$.

All PCR reactions were carried out in final volumes of $25 \mu 1$ containing $10 \mu \mathrm{l}$ of Methanol/heat isolated DNA or a $2.5 \mathrm{~mm} \mathrm{FTA}^{\circledR}$ treated snippet as initial templates, $0.2 \mathrm{mM}$ of each primer, $12.5 \mu 1$ of $2 \mathrm{x} \mathrm{HotStart}^{\circledR}$ Taq Master Mix (Qiagen, USA). Cycling conditions for genus-specific PCR were as the following: an initial activation at $95^{\circ} \mathrm{C} / 15 \mathrm{~min}$, 40 cycles of $\left(94^{\circ} \mathrm{C} / 30 \mathrm{sec}, 55^{\circ} \mathrm{C} / 30 \mathrm{sec}, 69^{\circ} \mathrm{C} /\right.$ $1 \mathrm{~min})$ and a final extension step at $69^{\circ} \mathrm{C} /$ $5 \mathrm{~min}$. Positive expected amplicons are of 291 bp. Cycling conditions for speciesspecific first reaction PCR were as follows: $95^{\circ} \mathrm{C} / 15 \mathrm{~min}, 40 \times\left(94^{\circ} \mathrm{C} / 30 \mathrm{sec}, 57^{\circ} \mathrm{C} / 35 \mathrm{sec}\right.$, $62^{\circ} \mathrm{C} / 70 \mathrm{sec}$ ) and a final extension step at $65^{\circ} \mathrm{C} / 5 \mathrm{~min}$. Concerning the Nested reaction, $2 \mu 1$ taken from the first rPLU6/rPLU5PCR reaction product were amplified using the following thermo-cycling scheme: $95^{\circ} \mathrm{C} /$ $15 \mathrm{~min}, 40 \mathrm{x}\left(94^{\circ} \mathrm{C} / 30 \mathrm{sec}, 54^{\circ} \mathrm{C} / 30 \mathrm{sec}, 66^{\circ} \mathrm{C} /\right.$ $40 \mathrm{sec}$ ) and $66^{\circ} \mathrm{C} / 5 \mathrm{~min}$ producing an amplicon of $205 \mathrm{bp}$ with $P$. falciparum and 120 bp with $P$. vivax species. PCR products were separated on basis of their sizes by electrophoresis onto agarose gels with appropriate concentrations; $1.2 \%$ for genus-specific PCR and $1.4 \%$ for species-specific Nested PCR products. Molecular size of visualized DNA bands when produced, were determined by extrapolation to the bands of a $100 \mathrm{bp}$ scale DNA ladder.

\section{Results}

Out of 121 blood samples collected from patients who visited health care centres seeking medical care in six malaria endemic localities of south-western region in Saudi Arabia, 69 were confirmed as P. falciparum malaria positive by expert microscopists using Giemsa stained thin and thick blood smears. No other Plasmodium species were found by microscopy. Parasitaemia levels findings were reported using a 1 to 4 crosses system and distributed by localities of origin (Tab. 2). Fifteen samples were found with $1+$ parasitaemia grade, 20 with $2+, 27$ with $3+$, and only 7 samples showed heavy parasitic load with a $4+$ parasitaemia level.

The analysis of 121 FTA $^{\circledR}$-cards spotted whole blood samples treated with Methanolfixation/Heat-extraction and FTA ${ }^{\circledR}$ purification kit separately by a $P$. genus-specific PCR and a $P$. species-specific Nested PCR showed the collected results. A representative agarose gel of separated amplification products issued from each protocol is illustrated (Fig. 1). In total, 75 out of 121 studied samples were found $P$. falciparum positive by at least one technique. These were used therefore as total positive cases to calculate diagnostic relative indices of each assay. In details, only 41/75 (55\%) Methanol-fixed/ Heat-extracted DNA templates and 59/75 (79\%) DNA templates purified by FTA ${ }^{\circledR}$ purification kit were found positive by the $P$. genus-specific conventional PCR. P. species-specific Nested PCR was able to amplify $P$. falciparum DNA in 68/75 (91\%) and $75 / 75(100 \%)$ samples using DNA templates isolated by the methanol-fixation/Heat-extraction and $\mathrm{FTA}^{\circledR}$ purification methods, respectively.

No PCR products were obtained by both techniques using three human quantified negative control DNA templates obtained 
from blood samples of healthy individuals living in non-endemic areas. 3D7 P. falciparum reference strain cultured parasites preserved on FTA $^{\circledR}$-cards and used herein as positive control showed positive results in all runs by both techniques.

PCR sensitivity increased with parasitaemia grades as estimated by microscopy. Using Methanol-Heat isolated DNA, $P$. genus-specific PCR was positive for $43 \%$ and $50 \%$ of blood samples with $1+\& 2+$ parasitaemia grades, respectively, and species- specific Nested PCR for $81 \%$ of samples with $1+$ parasitaemia level. Both PCR techniques showed a sensitivity of at least $93 \%$ using DNA templates isolated by FTA ${ }^{\circledR}$ purification reagent from samples with $3+\&$ 4+ parasitaemia levels.

The species-specific Nested PCR gave $100 \%$ sensitivity by using DNA templates of samples with 4+ parasitaemia grade isolated by both extraction methods. Details are given in tables $(1,2,3 \& 4)$ and figure (1).

Table 1: Set of oligonucleotides used in Plasmodium genus-specific PCR and $P$. falciparum/P. vivax species-specific-Nested-PCR (Ciceron et al, 1999; Snounou et al, 1993).

\begin{tabular}{|l|l|l|}
\hline Primer & Nucleotide Sequences $\left(5^{\prime}\right.$-3') & Nts \\
\hline \multicolumn{2}{|l|}{ Plasmodium Ssufw/Ssurv PCR (Ciceron et al, 1999$)$} & 21 \\
\hline Ssufw & AGTTACGATTAATAGGAGTAG & 21 \\
\hline Ssurv & CCAAAGACTTTGATTTCTCAT & 23 \\
\hline Plasmodium species-specific Multiplex-Nested-PCR (Snounou et al, 1993$)$ \\
\hline rPLU6 & TTAAAATTGTTGCAGTTAAAACG & 20 \\
\hline rPLU5 & CCTGTTGTTGCCTTAAACTT & 30 \\
\hline$P f F$ & TTAAACTGGTTTGGGAAAACCAAATATATT & 30 \\
\hline$P f R$ & ACACAATGAACTCAATCATGACTACCCGTC & 30 \\
\hline$P v F$ & CGCTTCTAGCTTAATCCACATAACTGATAC & 30 \\
\hline$P v R$ & ACTTCCAAGCCGAAGCAAAGAAAGTCCTTA \\
\hline
\end{tabular}

Table 2: Parasitaemia level determined by microscopic screening of malaria suspected incoming cases.

\begin{tabular}{|l|c|c|c|c|c|c|}
\hline Localities & Total collected samples & Negative & $1+$ & $2+$ & $3+$ & $4+$ \\
\hline Samtah & 48 & 14 & 9 & 10 & 13 & 2 \\
\hline Al-Ardah & 17 & 8 & 1 & 2 & 4 & 2 \\
\hline Jizan & 21 & 14 & 2 & 1 & 3 & 1 \\
\hline Tiwal & 8 & 4 & 0 & 0 & 2 & 2 \\
\hline Baisha & 20 & 8 & 0 & 7 & 5 & 0 \\
\hline Fifa & 7 & 4 & 3 & 0 & 0 & 0 \\
\hline Total & 121 & 52 & 15 & 20 & 27 & 7 \\
\hline
\end{tabular}

Table 3: Sensitivity, specificity, positive and negative predictive values of Plasmodium genus-specific PCR and $P$. species-specific nested PCR applied to DNA templates prepared from FTA $^{\circledR}$ dry blood spots by Methanol-fixation/ Heat-extraction and Whatman-FTA ${ }^{\circledR}$ purification reagent, and routine microscopic screening of Giemsa stained blood films

\begin{tabular}{|c|c|c|c|c|c|}
\hline Diagnostic technique & Specimens & Sensitivity & Specificity & +ve P.V. & -ve P.V. \\
\hline \multirow{2}{*}{$\begin{array}{l}\text { Plasmodium genus- } \\
\text { specific PCR }\end{array}$} & Methanol/Heat & $41 / 75(55 \%)$ & $46 / 46(100 \%)$ & $100 \%$ & $58 \%$ \\
\hline & FTA $®$ Reagent & $59 / 75(79 \%)$ & $46 / 46(100 \%)$ & $100 \%$ & $74 \%$ \\
\hline \multirow{2}{*}{$\begin{array}{l}\text { Plasmodium species- } \\
\text { specific-Nested-PCR }\end{array}$} & Methanol/Heat & $68 / 75(91 \%)$ & $46 / 46(100 \%)$ & $100 \%$ & $87 \%$ \\
\hline & FTA $^{\circledR}$ Reagent & $75 / 75(100 \%)$ & $46 / 46(100 \%)$ & $100 \%$ & $100 \%$ \\
\hline $\begin{array}{l}\text { Microscopic examina- } \\
\text { tion }\end{array}$ & $\begin{array}{l}\text { Thick blood } \\
\text { smear }\end{array}$ & $69 / 75(92 \%)$ & $46 / 46(100 \%)$ & $100 \%$ & $88 \%$ \\
\hline
\end{tabular}


Fig.1: Agarose gels of Plasmodium genus-specific conventional PCR (Panel A) and Plasmodium species-specific Nested PCR (Panel B) amplification products of malaria patients (S1, S2,..) blood DNA prepared by Methanolfixation/Heat-extraction (lanes $\mathrm{MH}$ ) versus Whatman-FTA ${ }^{\circledR}$ Reagent (lanes F). FTA ${ }^{\circledR}$-cards preserved cultured 3D7 reference strain control. A 100 bp molecular weight ladder separated in lanes $\mathrm{M}$.

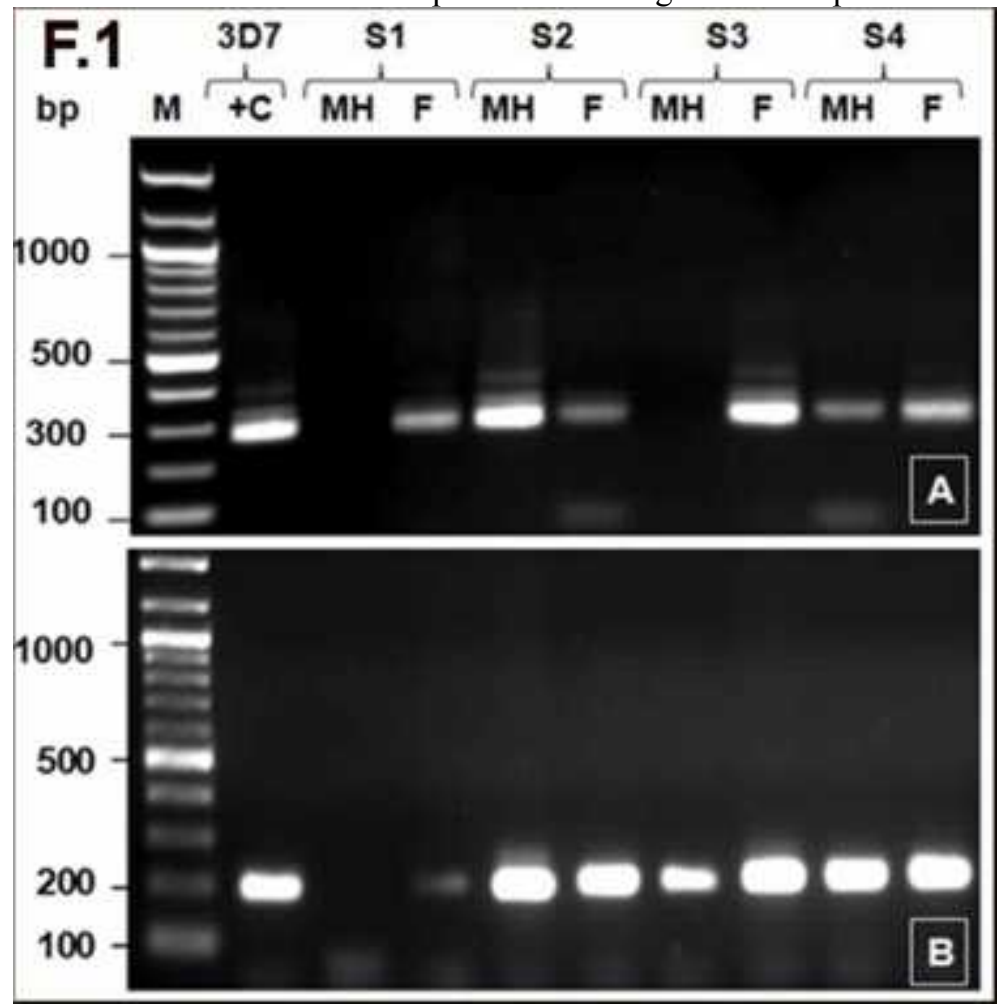

Table 4: Relative sensitivity of $P$. genus-specific PCR and Plasmodium species-specific Nested PCR applied to DNA templates prepared FTA ${ }^{\circledR}$ dry blood spots by Methanol-Heat and FTA $^{\circledR}$ purification reagent in relation to parasitaemia level.

\begin{tabular}{|l|l|c|c|c|c|c|}
\hline \multirow{2}{*}{$\begin{array}{l}\text { Parasitaemia } \\
\text { level }\end{array}$} & $\begin{array}{l}\text { Number of } \\
\text { Samples }\end{array}$ & \multicolumn{2}{|c|}{$\begin{array}{c}\text { +ve by P. genus-specific } \\
\text { PCR }\end{array}$} & $\begin{array}{c}\text { +ve by P. species-specific- } \\
\text { Nested-PCR }\end{array}$ & $\begin{array}{c}\text { +ve by mi- } \\
\text { croscopy }\end{array}$ \\
\cline { 3 - 7 } & $\begin{array}{c}\text { Methanol- } \\
\text { Heat }\end{array}$ & $\begin{array}{c}\text { FTA }^{\circledR} \text { Rea- } \\
\text { gent }\end{array}$ & $\begin{array}{c}\text { Metha- } \\
\text { nol/Heat }\end{array}$ & FTA ${ }^{\circledR}$ Reagent & $\begin{array}{c}\text { Thick blood } \\
\text { smear }\end{array}$ \\
\hline -ve & 46 & $0(0 \%)$ & $0(0 \%)$ & $0(0 \%)$ & $0(0 \%)$ & $0(0 \%)$ \\
\hline $1+$ & $15+6^{*}$ & $9(43 \%)$ & $11(52 \%)$ & $15+2 *(81 \%)$ & $15+6 *(100 \%)$ & $15(71 \%)$ \\
\hline $2+$ & 20 & $10(50 \%)$ & $16(80 \%)$ & $19(95 \%)$ & $20(100 \%)$ & $20(100 \%)$ \\
\hline $3+$ & 27 & $17(63 \%)$ & $25(93 \%)$ & $25(93 \%)$ & $27(100 \%)$ & $27(100 \%)$ \\
\hline $4+$ & 7 & $5(71 \%)$ & $7(86 \%)$ & $7(100 \%)$ & $7(100 \%)$ & $7(100 \%)$ \\
\hline
\end{tabular}

no*: number of samples negative by routine microscopic examination found positive by indicated molecular technique. These samples were estimated at minimal parasitaemia grade $(1+)$.

\section{Discussion}

Though the significant progress achieved by malaria control program in Saudi Arabia the disease remains a serious health issue, particularly in endemic south-western regions where $P$. falciparum is the most predominant species accounting for over $90 \%$ of autochthonous cases, and patients with clinically suspected malaria signs are frequently encountered (Omar et al, 1999; AlHarthi and Jamjoom, 2008). Also, an important number of imported malaria cases is being registered annually both, in endemic and non-endemic areas, among visitors coming for work or Ummrah and Hajj (Alkhalife, 2003; Al-Tawfiq, 2006).

The microscopic examination of Giemsastained blood smears remains the standard diagnostic procedure for malaria in Saudi Arabia. But, this method becomes more tedious and less sensitive in areas where malaria elimination strategies are expected to identify and treat actively all cases, especially chronic and asymptomatic carriers with 
very low parasitaemia levels (WHO, 2013). Therefore, more efficient field adapted diagnostic tools are vital to achieve more accurate results in active surveys. The only tests totally adapted to field screenings are the immunochromatographic devices, but the evaluation of these rapid diagnostic tests showed discrepant indices of specificity and the sensitivity was found to be limited by a minimum level of parasitaemia (Humar et al, 1997; Forney et al, 2001; Wongsrichanalai et al, 2007, Cheesbrough, 2009). Molecular techniques like PCR and some PCRderived techniques are being regarded as the gold standard malaria diagnostic tools in many research settings and health facilities because of their extremely high sensitivity and specificity (Hanscheid et al, 2002). In particular the use of ssu rRNA genes as DNA targets in malaria diagnosis by PCR has proven highly effective (Moody, 2002). Furthermore, available Nested-PCR methods can differentiate between Plasmodium species and detect mixed infections (Singh et al, 1996, Scopel et al, 2004). In this study, two PCR techniques targeting 18S ssu rRNA genes were assessed for malaria diagnosis in Saudi endemic areas, a $P$. genus-specific conventional PCR adapted from Ciceron et al. (1999) and a $P$. species-specific Nested PCR described initially by Snounou et al. (1993). Classically, molecular tools applied to malaria diagnosis have been performed using nucleic acids isolated from the whole blood samples, and this impeded seriously their use for active epidemiological surveys, especially in rural areas lacking adequate facilities for processing or maintaining blood samples in ideal conditions for posterior molecular analysis. Nevertheless, collection and transportation of blood samples as dry spots onto filter papers has proven to be a very useful and the inexpensive alternative which was increasingly used (Ataei et al, 2011; Pieter et al, 2014). In this study, 121 blood samples were collected onto WhatmanFTA $^{\circledR}$ cards from suspected patients in six malaria endemic districts of Saudi Arabia.
Whatman-FTA ${ }^{\circledR}$ cards were supposed to be impregnated with chemicals that stabilize DNA and RNA molecules within the fibre matrix (Ndungguru et al, 2005). It has been experimentally established that filter paper collected blood samples do not require immediate processing, can be preserved at room temperature, and once dried blood samples are not infectious offering the best substitute in settings with restricted access to the advanced diagnostic facilities (Li et al, 2004; Al-Harthi and Jamjoom, 2008). However, the success of DNA amplification with satisfactory levels by PCR depends greatly on the quality of the initial DNA template provided (Proux et al, 2011). Accordingly, the collected dry specimens were processed separately by the Methanol-fixation/Heatextraction and FTA ${ }^{\circledR}$-purification reagent to prepare DNA templates for both assessed PCR assays. Differences in the sensitivity of PCR detection of $P$. falciparum using DNA templates extracted by different methods have previously been described (Bereczky et al, 2005).

Seventy-five samples were found $P$. falciparum positive by at least one technique. These were used therefore, as total positive cases to calculate diagnostic relative indices of each assay. Although, the genus-specific conventional PCR was reported as $100 \%$ sensitive using DNA templates from whole blood samples by Ciceron et al. (1999), it showed less sensitivity $(79 \%)$ with filter dry blood spots, in this study. FTA ${ }^{\circledR}$ DNApurification kit provided better templates for the amplification, achieving $79 \%$ and $100 \%$ sensitivity compared to $55 \%$ and $91 \%$ when used in $P$. genus-specific PCR and $P$. species-specific Nested PCR, respectively. Both PCR techniques showed an increasing sensitivity in parallel with parasitaemia level; a sensitivity of at least $93 \%$ using DNA templates isolated by $\mathrm{FTA}^{\circledR}$ purification reagent from samples with $3+$ and 4+ parasitaemia levels. It was reported by the manufacturer that FTA $^{\circledR}$ DNA-purification kit ensures high quality of DNA templates for PCR 
analysis by removing heme, inhibitors and other possible contaminants (Whatman Ltd, 2002). Other authors reported that the biological material including blood samples kept on filter-paper appeared to conserve its genomic characteristics with less risk of contamination, loss or degradation during storage and handling in adequate conditions (Long et al, 1995; Scopel et al, 2004). False negative results obtained by using Methanol/Heat extracted DNA templates might reflect trapping of DNA in the filter-paper, as previously explained (Zhong et al, 2001).

$P$. species-specific Nested PCR applied to DNA templates prepared by FTA ${ }^{\circledR}$ purification reagent showed the highest sensitivity (100\%) detecting $P$. falciparum DNA in six samples misdiagnosed by the routine microscopic screening. The high occurrence of sub-microscopic parasitaemia levels detectable only by such sensitive PCR techniques has been reported as solid evidence that the chronic malaria cases were much more prevalent in endemic areas than previously estimated (Bottius et al, 1996; Okell et al, 2012). Also, identification of submicroscopic malaria infections by field adapted molecular protocols would be highly relevant for monitoring malaria epidemiology towards the achievement of sustainable malaria elimination in Saudi endemic areas.

\section{Conclusion}

Plasmodium species-specific Nested PCR achieved the best diagnostic performance indices with $100 \%$ sensitivity, specificity, Negative and positive predictive values when applied to dry blood spots collected onto FTA ${ }^{\circledR}$ cards and treated with FTA ${ }^{\circledR}$ purification reagent. This molecular protocol represents a viable alternative to classical microscopy for malaria diagnosis, particularly in remote rural settings and during active screening.

Only $P$. falciparum was found to be the causal agent in all collected samples both, by microscopic examination of the Giemsa stained thin blood smears and speciesspecific Nested PCR.

\section{Acknowledgements}

This work was financially supported by the Institute of Scientific Research and Revival of Islamic Heritage. The author would like to thank all medical staff and technicians in health care centers who contributed in this study.

\section{References}

Al-Harthi, SA, Jamjoom, MB, 2008: PCR assay in malaria diagnosis using filter paper samples from Jizan region, Saudi Arabia. J. Egypt. Soc. Parasitol. 38:693-706.

Al-Hassan, NA, Roberts, GT, 2002: Patterns of presentation of malaria in a tertiary care institute in Saudi Arabia. Saudi Med. J. 23, 5:562-7.

Alkhalife, IS, 2003: Imported malaria infections diagnosed at the Malaria Referral Laboratory in Riyadh, Saudi Arabia. Saudi Med. J. 24:106872.

Al-Seghayer, SM, Kenawy, MA, Ali, OT, 1999: Malaria in the kingdom of Saudi Arabia epidemiology and control. Scientific J. of King Faisal University; February special issue:6-20.

Al-Tawfiq, JA, 2006: Epidemiology of travelrelated malaria in a non-malarious area in Saudi Arabia. Saudi Med. J. 27:86-9.

Ann-Lee, M, Tan, CH, Aw, LT, Tang, CS, Singh, M, Lee, et al, 2002: Real-time fluorescence-based PCR for detection of malaria parasites. J. Clin. Microbiol. 40:4343-5.

Ataei, S, Nateghpour, M, Hajjaran, H, Edrissian, GH, Foroushani, AR, 2011: High specificity of semi-nested multiplex PCR using dried blood spots on DNA Banking Card in comparison with frozen liquid blood for detection of Plasmodium falciparum and Plasmodium vivax. J. Clin. Lab. Anal. 25:185-90.

Avila, SL, Ferreira, AW, 1996: Malaria diagnosis: a review. Braz. J. Med. Biol. Res. 29, 4: 431-3.

Bottius, E, Guanzirolli, A, Trape, JF, Rogier, C, Konate, L, Druilhe, P, 1996: Malaria: even more chronic in nature than previously thought; evidence for sub-patent parasitaemia detectable by the polymerase chain reaction. Trans. R. Soc. Trop. Med. Hyg. 90:15-9.

Cheesbrough, M, 1998: Importance of laboratory practice in district health care services. In: District Laboratory Practice in Tropical Countries, Part 1- Tropical Health Technology. Cambridge. 
Cheesbrough, M, 2009: Importance of laboratory practice in district health care services. In: District Laboratory Practice in Tropical Countries, $\left(2^{\text {nd }}\right.$ ed.) Update. Tropical Health Technology. Cambridge.

Ciceron, L, Jaureguiberry, G, Gay, F, Danis, M, 1999: Development of a Plasmodium PCR for monitoring efficacy of antimalarial treatment. J. Clin. Microbiol. 37, 1:35-8.

Coura, JR, Suárez-Mutis, M, Ladeia-Andrade, S, 2006: A new challenge for malaria control in Brazil: asymptomatic Plasmodium infection. Mem. Inst. Oswaldo Cruz 101, 3:229-37.

Daneshvar, C, Davis, TME, Cox-Singh, J, Rafa'ee, MZ, Zakaria, SK, Divis, PCS, Singh, B, 2009: Clinical and laboratory features of human Plasmodium knowlesi infection. Clin. Infect. Dis. 49:852-60.

El Sebai, MM, Makled, MK, 1987: Malaria in El-Taif, Saudi Arabia. J. Egypt. Soc. Parasitol. 17, 1:373-5.

Forney, JR, Magill, AJ, Wongsrichanalai, C, Sirichaisinthop, J, Bautista, CT, et al, 2001: Malaria rapid diagnostic devices: performance characteristics of the ParaSight F device determined in a multisite field study. J. Clin. Microbiol. 39, 8:2884-90.

Gilles, H, Warrell, DA, 2002: Essential Malariology, $\left(4^{\text {th }}\right.$. ed. $)$ : Arnold. London.

Hanscheid, T, Grobusch, MP, 2002: How useful is PCR in the diagnosis of malaria? Trends Parasitol. 18:395-8.

Humar, A, Ohrt, C, Harrington, MA, Pillai, D, Kain, KC, 1997: Parasight F test compared with the polymerase chain reaction and microscopy for the diagnosis of Plasmodium falciparum malaria in travelers. Am. J. Trop. Med. Hyg. 56:44-8.

Li, CC, Beck, IA, Seidel, KD, Frenkel, LM, 2004: Persistence of human immunodeficiency virus Type 1 Subtype B DNA in dried-blood samples on FTA Filter Paper. J. Clin. Microbiol. 42, 8:3847-9.

Long, GW, Fries, L, Watt, GH, Hoffman, SL, 1995: Polymerase chain reaction amplification from Plasmodium falciparum on dried blood spots. Am. J. Trop. Med. Hyg. 52:344-6.

Mangold, KA, Manson, RU, Koay, ES, Stephens, L, Regner, M, et al, 2005: Real-time PCR for detection and identification of Plasmodium spp. J. Clin. Microbiol. 43:2435-40.

Mbugi, EV, Mutayoba, BM, Malisa, AL, Balthazary, ST, Nyambo, TB, et al, 2006: Drug resistance to sulphadoxine-pyrimethamine in Plasmodium falciparum malaria in Mlimba, Tanzania. Malar. J. 5:94.

MOH, 2005: Health statistic book, Ministry of Health. http://www.moh.gov.sa /statistics/1425/ Annual_Report.htm,.

Ndungüu, J, Taylor, NJ, Yadav, J, Aly, H, Legg, JP, Aveling, T, et al, 2005: Application of FTA technology for sampling, recovery and molecular characterization of viral pathogens and virus-derived transgenes from plant tissues. Virol. J. doi: 10.1186/1743-422X-2-45.

Okell, LC, Bousema, T, Griffin, JT, Ouedraogo, AL, Ghani, AC, Drakeley CJ, 2012: Factors determining the occurrence of submicroscopic malaria infections and their relevance for control. Nat. Commun. 3:1237-42.

Omar, MS, Malik, GM, Al-Amari, OM, Abdalla, SE, Moosa, RA, 1999: The rapid manual Para-Sight-F test for diagnosing Plasmodium falciparum malaria in Saudi Arabia. Ann. Saudi Med. 19, 2:159-62.

Perandin, F, Manca, N, Calderaro, A, Piccolo, G, Galati, L, Ricci, L, Medici, MC, et al, 2004: Development of a real-time PCR assay for detection of Plasmodium falciparum, Plasmodium vivux, and Plasmodium ovule for routine clinical diagnosis. J. Clin. Microbiol. 42:1214-9.

Pomper, GJ, Wu, Y, Snyder, EL, 2003: Risks of transfusion-transmitted infections: Curr. Opin. Hematol. 10, 6:412-8.

Proux, S, Suwanarusk, R, Barends, M, Zwang, J, Price, RN, et al, 2011: Considerations on the use of nucleic acid-based amplification for malaria parasite detection. Malar. J. 10:323.

Scopel, KG, Fontes, CJ, Nunes, AC, Horta, MF, Braga, EM, 2004: Low sensitivity of nested PCR using Plasmodium DNA extracted from stained thick blood smears: an epidemiological retrospective study among subjects with low parasitaemia in an endemic area of the Brazilian Amazon region. Mal. J. 3:8

Scopel, KKG, Fontes, CJF, Nunes, AC, Horta, MF, Braga, TA, 2004: High prevalence of Plasmodium malariae infections in a Brazilian Amazon endemic area (Apiacas-Mato Grosso State) as detected by polymerase chain reaction. Acta Trop. 90:61-4.

Singh, B, Cox-Singh, J, Miller, AO, Abdullah, MS, Snounou, G, Rahman, HA, 1996: Detection of malaria in Malaysia by nested polymerase chain reaction amplification of dried blood 
spots on filter papers. Trans. R. Soc. Trop. Med. Hyg. 90:519-21.

Smit, PW, Elliott, I, Peeling, RW, Mabey, D, Newton, PN, 2014: Review Article: An overview of the clinical use of filter paper in the diagnosis of tropical diseases Am. J. Trop. Med. Hyg., 90, 2:195-210.

Smit, PW, Elliott, I, Peeling, RW, Mabey, D, Newton, PN, 2014: Review Article: An Overview of the Clinical Use of Filter Paper in the Diagnosis of Tropical Diseases Am. J. Trop. Med. Hyg. 90, 2:195-210.

Snounou, G, Viriyakosol, S, Jarra, W, Thaithong, S, Brown, KN 1993: Identification of the four human malaria parasite species in field samples by the polymerase chain reaction and detection of a high prevalence of mixed infections. Mol. Biochem. Parasitol. 58:283-92.

Tuteja, R, 2007: Malaria, An overview. FEBS J. 274:4670-9.

Vassallo, L, Khan, MA, Edeson, JF, 1985: Epidemiological aspects and clinical implica- tions of malaria as seen in Jeddah. Saudi Arabia. Ann. Trop. Med. Parasitol. 79, 4:349-55.

Warrell, DA, 1993: Leishmaniasis, malaria and schistosomiasis in Saudi Arabia. Saudi Med. J. 14, 3:203-8.

WHO, 1991: Basic Malaria Microscopy. WHO, Geneva, Switzerland.

WHO, 2005: Overview of malaria control activities and programme progress. http://rbm.who. int/wmr2005/profiles/saudiarabia.pdf.

WHO, 2013: World Malaria Report 2013. Geneva: World Health Organization Press; 2013.

Wongsrichanalai, C, Barcus, MJ, Muth, S, Sutamihardja, A, Wernsdorfer, WH, 2007: A review of malaria diagnostic tools: microscopy and rapid diagnostic test (RDT). Am. J. Trop. Med. Hyg. 77:119-27.

Zhong, KJY, Salas, CJ, Shafer, R, Cobanov, A, Gasser, RA, et al, 2001: Comparison of IsoCode STIX and FTA gene guard collection matrices as whole-blood storage and processing devices for diagnosis of malaria by PCR. J. Clin. Microbiol. 39:1195-6. 